\title{
PHENOTYPIC VARIABILITY IN FEIJOA FRUITS [Acca sellowiana (O. Berg.) Burret] ON INDIGENOUS LANDS, QUILOMBOLAS COMMUNITIES AND PROTECTED AREAS IN THE SOUTH OF BRAZIL ${ }^{1}$
}

\author{
LIDO JOSÉ BORSUK ${ }^{2}$, LUCIANO SAIFERT ${ }^{3}$, JUAN MANUEL OTALORA VILLAMIL ${ }^{4}$, \\ FERNANDO DAVID SÁNCHEZ MORA ${ }^{5}$, RUBENS ONOFRE NODARI ${ }^{6}$
}

\begin{abstract}
Phenotypic studies with native fruits are important sources of information for understanding the status of conservation of plant species, especially populations in protected areas (PAs). Fruits of 18 populations of feijoa [Acca sellowiana (O. Berg.) Burret] present in three kind of PAs, Quilombolas Communities (QLs), Indigenous Lands (ILs) and Conservation Units (CUs) were evaluated with the aim to characterize the phenotypic variability. Fruits were harvested at maturity and eight morphological descriptors were measured: diameter, length, total weight, pericarp weight, pulp weight, pericarp thickness, pulp yield and solid soluble contents ( ${ }^{\circ} \mathrm{Brix}$ ). The results revealed the existence of large morphological variability for all traits, with significant differences among all populations and among those populations grouped in QLs, TIs and UCs, particularly to the total weight and peel thickness. There was a clear formation of five major clusters of genetic dissimilarity. In addition, two Uruguayan type populations and 16 Brazilian type populations showed contrast means for most of the evaluated traits. The lower variability on fruit characters found in plants collected in areas of traditional people but not in CUs suggests the existence of selection processes of feijoa genotypes on those areas.
\end{abstract}

Index terms: Goiabeira-serrana, pineapple-guava, traditional people, in situ on farm conservation.

\section{VARIABILIDADE FENOTÍPICA EM FRUTOS DE GOIABEIRA-SERRANA [Acca sellowiana (O. Berg.) Burret] EM TERRAS INDÍGENAS, COMUNIDADES QUILOMBOLAS E EM UNIDADES DE CONSERVAÇÃO NO SUL DO BRASIL}

RESUMO - Estudos fenotípicos com frutas silvestres são importantes fontes de informação para entendimento do estado de conservação das espécies vegetais, sobretudo em populações de plantas em áreas protegidas. Frutos de 18 populações de goiabeira-serrana [Acca sellowiana (O. Berg.) Burret], internacionalmente denominada de feijoa, presentes em Comunidades Quilombolas (QLs), Terras Indígenas (TIs) e em Unidades de Conservação (UCs) foram avaliados, com o objetivo de caracterizar variabilidade fenotípica. Os frutos foram coletados na maturação, e oito características foram avaliadas: diâmetro, comprimento e peso do fruto, peso da casca, peso de polpa, espessura da casca, rendimento de polpa e teor de sólidos solúveis totais ( ${ }^{\circ}$ Brix). Os resultados revelaram a existência de significativa variabilidade morfológica para todas as características avaliadas, havendo diferenças significativas entre todas as populações e entre as - agrupadas em QLs, TIs e UCs, em especial para o peso total e a espessura da casca. Houve clara formação de cinco grupos principais de dissimilaridade, com separação de duas populações para o tipo Uruguai e 16 para tipo Brasil. O fato da ocorrência da menor variabilidade nos frutos encontrado em plantas de áreas de povos tradicionais, sugere a existência de processos de seleção de genótipos da goiabeira-serrana nestas áreas.

Termos para indexação: Feijoa, pineaple-guava, povos tradicionais, conservação in situ on farm.

1(Paper 197-15). Received August 06, 2015. Accepted November 26, 2015.

${ }^{2}$ Agronomist, Graduate Student, Graduate Program on Plant Genetic Resources, Federal University of Santa Catarina (UFSC) Florianópolis, Brazil. E-mail: lidoborsuk@hotmail.com

${ }^{3}$ Agronomist, MSc. Student. Graduate Program in Plant Genetic Resources, UFSC - Florianópolis, Brazil. E-mail: lucianosaifert@ hotmail.com

${ }^{4}$ Agronomist, PhD Student, Graduate Program in Plant Genetic Resources, UFSC - Florianópolis, Brazil. E-mail: juanmanuelotalora@ gmail.com

${ }^{5}$ Agronomist, MSc., Engineering Agronomic Faculty, Experimental Campus La Teodomira, Technical University of Manabí (UTM), Ecuador. Email: fdsanchez@utm.edu.ec

${ }^{6}$ Agronomist, PhD., Graduate Program in Plant Genetic Resources, UFSC - Florianópolis, Brazil. E-mail: rubens.nodari@ufsc.br 


\section{INTRODUCTION}

The Acca sellowiana (O. Berg.) Burret is a native species of the south of Brazil, Argentina, Uruguay, and Paraguay (MATTOS, 1986; 1990), it is popular known as pineapple guava, guavasteen or feijoa (DONAZZOLO et al., 2015). The pulp is cream colored, has a distinctive sweet-acidulated and aromatic flavor (MATTOS, 1986; DUCROQUET et al., 2000). The fruits are edible berries of different shapes and sizes, some exceeding 200 grams (DONAZZOLO, 2012; NODARI et al., 1997). Besides the consumption in natura, they can be processed for the production of juices, jellies, ice creams, among others (SHARPE et al., 1993; THORP; BIELESKI, 2002).

In Brazil, A. sellowiana can be found naturally in the states of Rio Grande do Sul, Santa Catarina and Paraná (MATTOS, 1986). It is a fruit tree, in the way of domestication in its center of origin that has high potential for food use in the region and is considered of natural occurrence (DUCROQUET et al., 2000; NODARI et al., 2008). In the State of Santa Catarina, the feijoa occurs most frequently in areas with altitudes above 1000 meters and with formation of forests and araucaria forests (MATTOS, 1990; DUCROQUET et al., 2000). The cultivation of feijoa in the south region of Brazil shows promising, since in the State of Santa Catarina in 2012 were registered 15 farmers who cultivated 11 ha, which produce 86.8 tons/year of fruits (CENTRO DE SOCIOECONOMIA E PLANEJAMENTO AGRICOLA, 2013). According to Moretto et al. (2014) the species was introduced and acclimatized in countries outside its natural area of occurrence, such as France, Italy, Russia, New Zealand, United States, Israel and Colombia.

Esemann-Quadros et al. (2008) carried out anatomical studies of this species fruits, highlighting the existence of breeding programs and economic exploitation in other countries. In Brazil, research revealed the existence of recognition by family farmers of differentiated forms and flavors for the feijoa present in their properties. Several of the farmers identified superior genotypes, demonstrating the importance of in situ on farm conservation (SANTOS et al., 2009).

Natural populations of feijoa are also present in Protected Areas (PAs) such as areas traditionally occupied by Quilombola Communities (QLs), Indigenous Lands (ILs), and Conservation Units (CUs). The natural distribution area of the feijoa has suffered intense anthropization of the landscape in the last centuries, with fragmentation of the florets and loss of biodiversity.

However, until now, no study has been carried out on the morphological variability of feijoa fruits in these areas. An analysis of these materials may reveal the existence of superior genotype selection processes and the formation of certain patterns in the fruits characteristics of this species that are being used and managed by the indigenous and quilombolas. Although the CUs have differentiated human functions and interventions over time, knowledge of the characteristics variation of feijoa fruits in these areas may serve as relevant information for ICMBio conservation programs, as well as in programs for use and genetic improvement.

Thus, the aim of this study was to evaluate the phenotypic diversity of feijoa fruits in areas of QLs, ILs and CUs in the south of Brazil, in order to identify morphological differences associated with the anthropic selection processes.

\section{MATERIAL AND METHODS}

The evaluations of the feijoa fruits characteristics were carried out from February to May 2014 in 18 populations located in the states of Rio Grande do Sul, Santa Catarina and Paraná, of five populations from ILs, five from QLs and eight from CUs (Table 1). The accomplishment of this study was conditioned to the legal aspects of Provisional Measure 2.186-16/2001 that regulates Scientific Research, the Bioprospection and the Technological Development. Thus, for the accomplishment of this research, we first obtained the Prior Consent with the Traditional People and, later, the approval by the National Institute of Historic and Artistic Heritage (IPHAN) and for the Protected Areas the authorization was granted by the Chico Mendes Institute of Biodiversity Conservation (ICMBio), Processes $n^{\circ} 01450.126452013-82$ and 27697$1 / 2011$, respectively.

In the field, 362 plants were selected, which were photographed and georeferenced with the aid of GPS (Global Position System). From each plant, 10 fruits were harvested at physiological maturation stage, totaling 3620 fruits, which were put in plastic bags, identified, packed in thermal boxes and transported to the Laboratory of Plant Physiology of Development and Genetics of the Federal University of Santa Catarina - UFSC, remaining in the refrigerator until the analysis. To the fruits characterization, we measured fruit diameter and length $(\mathrm{cm})$, total weight $(\mathrm{g})$, pericarp weight $(\mathrm{g})$, pulp weight $(\mathrm{g})$, pericarp thickness $(\mathrm{cm})$ and solid soluble contents ( ${ }^{\circ}$ Brix). The pulp yield expressed 
in percentage (\%) was obtained by multiplying 100 by the quotient of the pulp weight by the fruit total weight.

For the data analysis, we used descriptive statistics and multivariate analysis. In the multivariate analysis, the data of the 18 feijoa populations were previously normalized and submitted to Principal Component Analysis (PCA) and hierarchical grouping. For the grouping (HCAHierarchical cluster dendrogram) of the data, the Euclidian Distance was used as a measure of dissimilarity and, in the delimitation of the groups, the UPGMA method (SNEATH;SOKAL,1973). The analysis of descriptive statistics was carried out in Excel 2007 program and in the R version 3.1.3 free software (R Core Team, 2014).

\section{RESULTS AND DISCUSSION}

The descriptive analysis of fruit characteristics in feijoa populations present in QLs, ILs and CUs are shown in Table 2. The coefficients of variation ranged from $11.7 \%$, for the total soluble solids up to $56.3 \%$ for the fruit total weight, indicating a great phenotypic variability of feijoa in the studied areas. Degenhardt et al. (2003), evaluating half-sib families of feijoa, verified that the characteristics of each family's fruits varied between plants and between years, being influenced by the environmental effect, diverse in the different years.

The average diameter of the feijoa fruits from all populations was $3.5 \mathrm{~cm}$ and the average length was $4.2 \mathrm{~cm}$ (Table 2). While the lowest values were observed in the QLCG and QLPT, both Quilombola communities, the highest values of diameter and length of fruit in Indigenous Lands were revealed in the TIPL, 3.8 and $4.6 \mathrm{~cm}$, respectively. These two characteristics were more variable in the QLs and showed smaller variation in the ILs.

Regarding the fruit weight, the general average reached $31.6 \mathrm{~g}$. The QL populations showed the lowest average value $(26.8 \mathrm{~g})$; while the ILs and CUs provided fruits with average weights of 31.0 and $37.0 \mathrm{~g}$, respectively (Table 2). The fruit average weight per population ranged from $10.8 \mathrm{~g}$ (QLPT) to $50.2 \mathrm{~g}$ (QLMC) in the QLs, from 24.1g (TIMC) to $37.0 \mathrm{~g}$ (TIPL) in the ILs and in the CUs from $27.4 \mathrm{~g}$ (UCPNSG) to $58.1 \mathrm{~g}$ (UCPNSJ). The great variation for this character is also expressed in terms of coefficient of variation that was $74.9 \%$ and $49.1 \%$ in the QLs and CUs populations, respectively. The minimum value of fruit weight per plant found in the QLs was 5.8g while the maximum value was 115.7 g. In the CUs, the minimum value was $7.4 \mathrm{~g}$ and the maximum was $125.9 \mathrm{~g}$ (Table 2). These results are in agreement with other studies where the fruit weight ranged from 31 to $200 \mathrm{~g}$ (NODARI et al., 1997; DEGENHARDT et al., 2003). Donazzolo (2012) found high values of fruit weight (ex: $173.0 \mathrm{~g}$ for 1017 genotype) when studying the feijoa intensively managed by farmers or in urban yards. In Brazil, the commercial varieties, the average fruit weight ranged from $90 \mathrm{~g}$ (Nonante) to $150 \mathrm{~g}$ (SCS 414-Mattos) (DUCROQUET et al., 2008). In Colombia, the fruit weight of the Quimba cultivar ranged from 21.1 to 52.1g (MARTÍNEZ-VEGA et al., 2008).

The fruits collected in QLMC, TIPL and UCPNSJ showed the highest values for diameter, length and total weight. Puppo et al. (2014), evaluating descriptors for feijoa characterization, verified that these characters are discriminating descriptors, since they detect greater variation between plants than within plants. In the characterization of a population of 300 feijoa plants in the region of Sakarya (Turkey), Beyhan and Eyduran (2011), using the same three descriptors, 16 selected genotypes values of 0.23 to $0.39 \mathrm{~cm}$ were obtained for diameter, 0.28 to $0.60 \mathrm{~cm}$ for length and 21.7 to $40.0 \mathrm{~g}$ for fruit weights.

The average pericarp thickness of all fruits was $0.5 \mathrm{~cm}$ (Table 2). In the fruits collected in the QLs, averages of 0.4 were recorded and in the ILs and CUs they were 0.5 and $0.6 \mathrm{~cm}$, respectively. In the QLs, the fruits of the QLPT population developed pericarp with a thickness of $0.3 \mathrm{~cm}$, while the QLMC produced fruits with the highest value of this characteristic, $0.6 \mathrm{~cm}$. In the ILs, the pericarp thicknesses ranged from 0.4 to $0.6 \mathrm{~cm}$ in fruits of the TICD and TICHR populations, respectively. In the CUs, the thicknesses were from 0.4 (UCSFP) to $0.6 \mathrm{~cm}$ (UCPL, UCPNA, UCPNAS and UCPNSJ). In Uruguay, Silveira et al. (2015) found statistical differences in feijoa tree pericarp thickness, where the four selections showed the thinnest thicknesses with an average of $0.31 \mathrm{~cm}$, compared to the highest thickness found $(0.69 \mathrm{~cm})$. These authors mentioned that the selected accessions could be of greater interest because they present a greater edible portion in the fruit.

Thicker pericarp $(0.6 \mathrm{~cm})$ was more frequent in fruits of Conservation Units populations (50\%), compared to $20 \%$ in Indigenous or Quilombola Lands. In addition, in both QLMC and TICHR, where fruits with a pericarp thickness of $0.6 \mathrm{~cm}$ were found, this characteristic showed great variability ( $\mathrm{CV}=37.5 \%$ and $64.6 \%$, respectively). These results 
allow to raise the hypothesis that this characteristic is related to the selection pressure exerted by the traditional people, for fruits with more pulp. However, it is necessary to investigate whether the fruit size and the pericarp thickness are associated with the fruit domestication process, because they are characteristics that interfere in the final yield. On the other hand, the CUs showed fruits with greater pericarp thickness comparatively to the QLs and ILs.

The pulp yield showed an overall average of $31.6 \%$. In the QLs, the average yield for the pulp was $32.6 \%$, similar values were found in the ILs and CUs with 32.2 and $30.0 \%$, respectively. These yields are similar to those recorded by the Nonante and SCS 414 Mattos cultivars, which showed pulp yields from $27 \%$ to $37 \%$ (DUCROQUET et al., 2008). The pulp yield variation (15\%) and the minimum value $(18.4 \%)$ were similar in the fruits collected in QLs and CUs, while the maximum value in the QLs was $49.5 \%$ and in the CUs was $42 \%$ (Table 2). Degenhardt et al. (2003) were evaluating progenies of two half-sib families, found pulp yields varying from 23.5 to $33.7 \%$.

The total soluble solids content average (TSS) of all fruits was $10.8^{\circ} \mathrm{Brix}$, with average values of $11.0 ; 10.8$ and $10.4{ }^{\circ}$ Brix for the fruits collected in QLs, ILs and CUs, respectively (Table 2). In the TICD and UCPNAS populations, the TSS content of the fruits reached 17.8 and $16.5^{\circ} \mathrm{Brix}$, respectively, much higher than those found in commercial varieties. Fruits of the Nonante and SCS 414 Mattos cultivars recorded TSS from 10 to 13 ${ }^{\circ}$ Brix (DUCROQUET et al., 2008) and in the Quimba cultivar (Colombia), TSS values ranged between 10.3 and $11.6^{\circ}$ Brix (MARTÍNEZ-VEGA et al., 2008). Beyhan and Eyduran (2011) recorded genotypes with TSS of $10.0^{\circ}$ Brix (Mestan-3, Mestan-5) and 16.0 ${ }^{\circ}$ Brix (Mestan-25).

Comparing to the QLs and ILs, the lowest values of pulp yield and total soluble solids were observed in the CUs, but fruits with higher values for pericarp thickness, diameter, length and fruit weight. As the pulp yield also depends on the pericarp thickness, this characteristic could have been affected by the selection practiced by the traditional communities.

In this study, the fruit morphological variation of the plants that occur in its center of origin represents an important indicator in terms of strategies of use and conservation of feijoa. The high fruits variability of this species is independent of the plants being accessed in anthropic areas, in this case occupied by traditional people for a long period, or they belong to the Conservation Units, with restricted human influence. This morphological variation is presented as an opportunity for the development of new varieties with different quantitative characteristics (size, shape) and qualitative (pulp color, flavor and other) attributes according to the demand of the consumer market.

In this study, we also verified the existence of the Uruguay type and Brazil type, already described by Mattos (1986) and Ducroquet et al. (2000). The data evidenced the magnitude of the differences between the two feijoa types, for several characteristics, with emphasis on total weight, pericarp weight and pulp weight, and only the total soluble solids values were higher in Uruguay type plants (Table 3). In addition, Uruguay type fruits collected in QLCG and QLPT showed lower variation for all characteristics evaluated, corroborating with previously reported studies (NODARI et al., 1997; DONAZZOLO, 2012), who also emphasized this difference between the two types. According to Amarante et al. (2008), the Brazil type showed greater pericarp thickness than the Uruguay type.

The grouping analysis also reinforces the existence of the two types: The Uruguay type exclusively composed of the QLCG and QLPT populations, and the second group, Brazil type, represented by the other populations evaluated (Figure 1). The cophenetic correlation coefficient of the resulting dendrogram was 0.98 , indicating that the groupings formed are highly consistent. The genetic distances between populations within each group were lower than those among populations of different groups. The populations classified as Brazil type were grouped into subgroups, but the subgroup formed by UCPNSJ and QLMC populations showed well-defined separation. These two populations showed the highest values for total weight and pericarp weight, which justifies this association. The same cannot be extended to the other (three) subgroups.

On the other hand, the grouping analysis also revealed that feijoa populations from areas of traditional people are more grouped by the pulp yield trait, followed by total soluble solids. For the populations from the CUs, it is precisely the opposite in most cases; the pericarp thickness is the variable that provides the greatest association of these populations. It is important to note that this variable showed the second largest variance among the characters analyzed.

The Principal Components Analysis (PCA) of the 18 feijoa populations showed that the selfvalues of PC1 and PC2 explain $89.84 \%$ of the data 
variation (Table 4). The first major component explained $69.8 \%$ of the variability, through the following variables: diameter (0.42), length (0.41), total weight $(0.42)$, pericarp weight $(0.42)$ and pulp weight $(0.41)$; while the second component explained $20.06 \%$ of the variability, where the variables that contributed to explain the variation were pulp yield $(-0.63)$ and total soluble solids $(-0.65)$.

The QLCG and QLPT populations are strongly correlated with each other in function of pulp yield and total soluble solids, being independent of the other populations and presenting a strong negative correlation. There was also a strong correlation between the group of UCPF, TIPL, TICHR, QLMC, QLCN, TISJC, QLPL and UCPNSJ populations, and the characteristics of fruit diameter, length, total weight, pericarp weight and pulp weight were the ones that contributed the most to discriminate these populations from the other for the UCPNA and UCPL populations, as well as UCPNAS and UCPNSG the pericarp thickness was the characteristic of higher expression (Figure 2).

Compared with Conservation Units, it is possible to affirm that there is less variation of the morphological characters between the fruits of traditional people areas. The results of the present study suggest that in these areas, the selection processes are being carried out for the analysed morphological characters and, consequently, the domestication of $A$. sellowiana plants or populations at different levels, associated with landscapes that are mostly anthropic.

The morphological analysis for the quantitative traits showed evidences that $A$. sellowiana is being selected by the indigenous and quilombolas. In spite of the differences between the characteristics analysed in the different groups studied, a greater similarity was observed between the fruits of the QLs and ILs populations.

TABLE 1- Localization of feijoa populations and number of plants sampled in Quilombola Communities (QLs), Indigenous Lands (ILs) and Conservation Units (CUs) in the south of Brazil.

\begin{tabular}{|c|c|c|c|}
\hline Abbreviation & Name & Number of plants & State $^{3}$ \\
\hline \multicolumn{4}{|c|}{ QUILOMBOLA COMMUNITIES $^{1}$} \\
\hline QLCG & Quilombo Maçambique & 45 & (RS) \\
\hline QLCN & Quilombo Invernada dos Negros & 35 & $(\mathrm{SC})$ \\
\hline QLMC & Quilombo Mato Grande & 27 & $(\mathrm{RS})$ \\
\hline QLPL & Quilombo Adelaide Maria Batista & 12 & $(\mathrm{PR})$ \\
\hline QLPT & Quilombo Faxina e Rincão do Couro & 17 & $(\mathrm{RS})$ \\
\hline \multicolumn{4}{|c|}{ INDIGENOUS LANDS $^{1}$} \\
\hline TICD & Terra Indígena Cacique Doble & 35 & (RS) \\
\hline TICHR & Terra Indígena Ligeiro & 9 & $(\mathrm{RS})$ \\
\hline TIMC & Terra Indígena Monte Caseiros & 15 & $(\mathrm{RS})$ \\
\hline TIPL & Terra Indígena Palmas & 8 & $(\mathrm{PR})$ \\
\hline TISJC & Terra Indígena São José do Cerrito & 49 & $(\mathrm{SC})$ \\
\hline \multicolumn{4}{|c|}{ CONSERVATION UNITS $^{2}$} \\
\hline $\mathrm{UCMC}$ & Estação Ecológica de Aracuri-Esmeralda & 14 & (RS) \\
\hline UCPF & Floresta Nacional de Passo Fundo & 21 & $(\mathrm{RS})$ \\
\hline UCPL & Refugio da Vida Silvestre dos Campos de Palmas & 14 & $(\mathrm{PR})$ \\
\hline UCPNA & Parque Nacional das Araucárias & 19 & $(\mathrm{SC})$ \\
\hline UCPNAS & Parque Nacional de Aparados da Serra & 9 & $(\mathrm{RS})$ \\
\hline UCPNSG & Parque Nacional Serra Geral & 11 & $(\mathrm{RS})$ \\
\hline UCPNSJ & Parque Nacional de São Joaquim & 15 & $(\mathrm{SC})$ \\
\hline UCSFP & Floresta Nacional de São Francisco de Paula & 7 & $(\mathrm{RS})$ \\
\hline
\end{tabular}

${ }^{1}$ License number 27697/2011 issued by Chico Mendes Institute for the Biodiversity Conservation (ICMBio). ${ }^{2}$ License number 01450.12645/2013-82 issued by National Historic and Artistic Heritage Institute (IPHAN). ${ }^{3}$ State: RS (Rio Grande do Sul), SC (Santa Catarina) and PR (Paraná). 


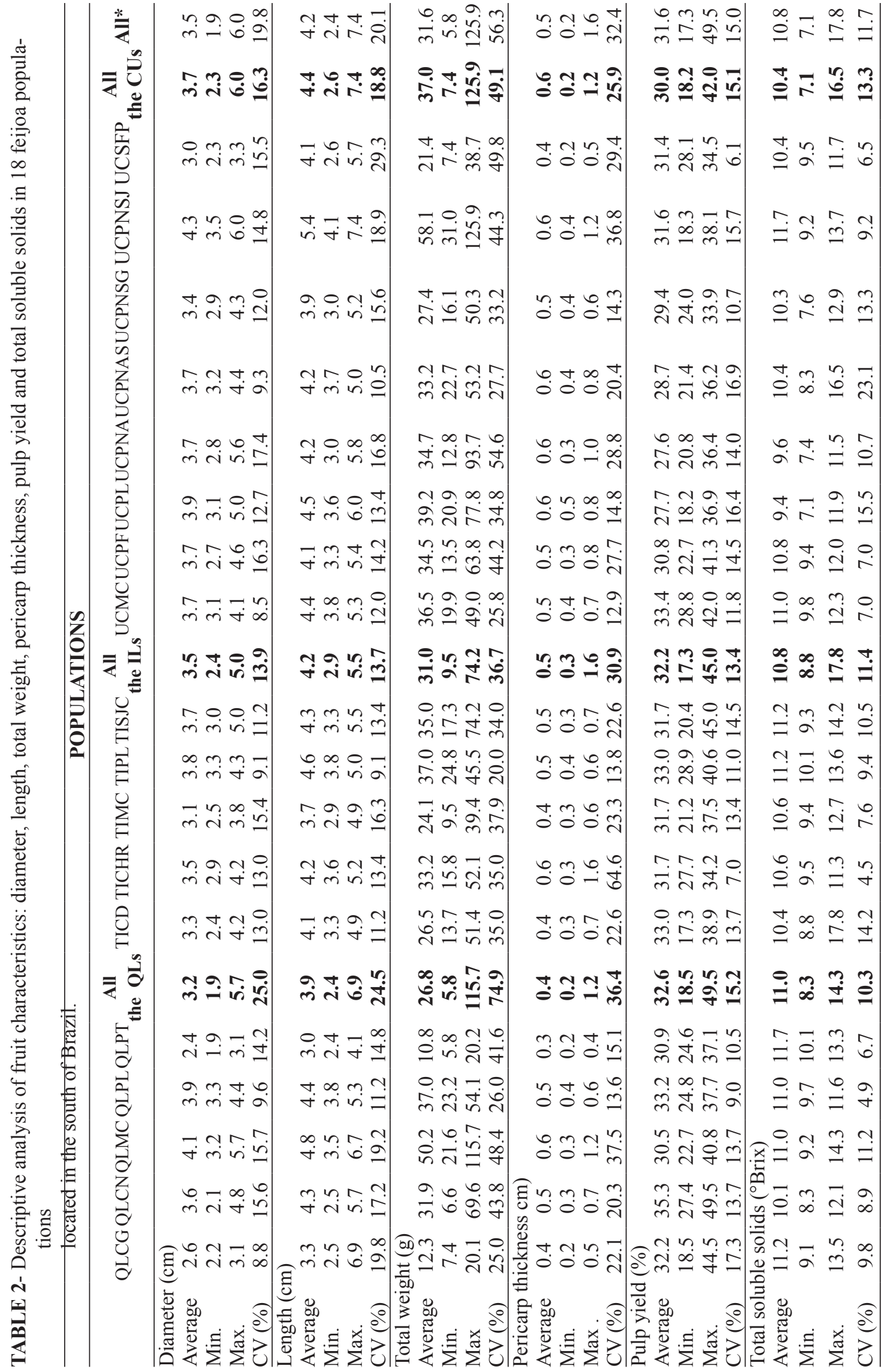




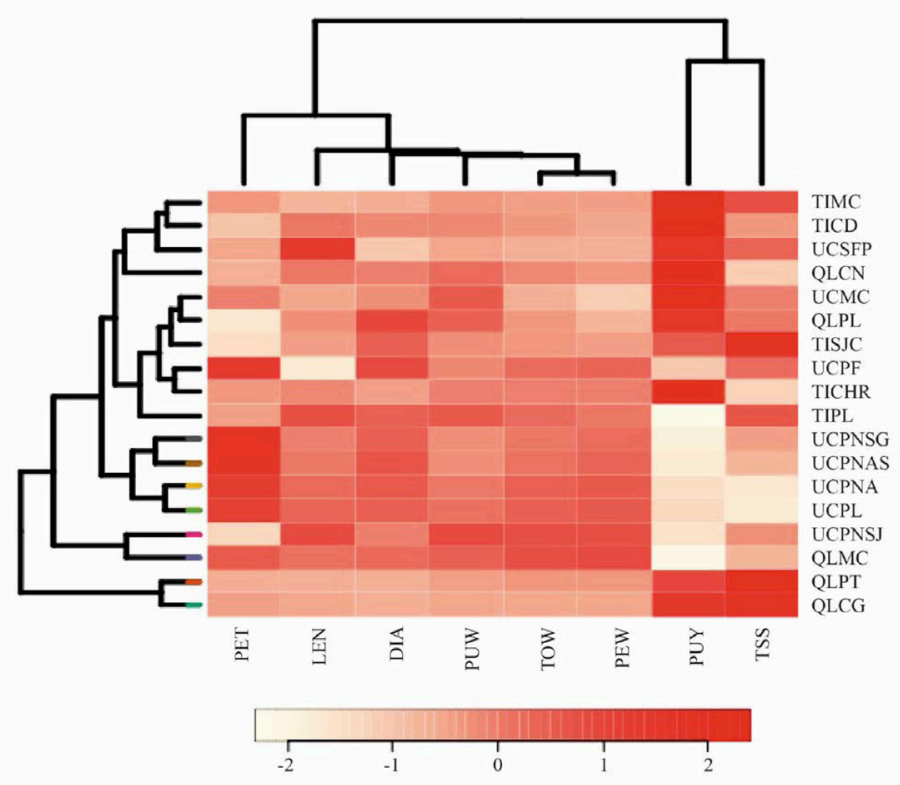

FIGURE 1-Dendrogram of similarity based on Euclidian Distance by the UPGMA agglomeration method from the descriptors: diameter (DIA), length (LEN), total weight (TOW), pericarp weight (PEW), pulp weight (PUW), pulp yield (PUY), pericarp thickness (PET) and total soluble solids (TSS) analyzed in A. sellowiana fruits from 18 plant populations (See Table 1) in Quilombola Communities (QLCG, QLCN, QLMC, QLPL, QLPT); Indigenous Lands (TICD, TICHR, TIMC, TIPL, TISJC) and Conservation Units (UCMC, UCPF, UCPL, UCPNA, UCPNAS, UCPNSG, UCPNSJ) in the south of Brazil. Bar bellow Figure represent the Euclidian distance. Cophenetic correlation coefficient $=0,979$.

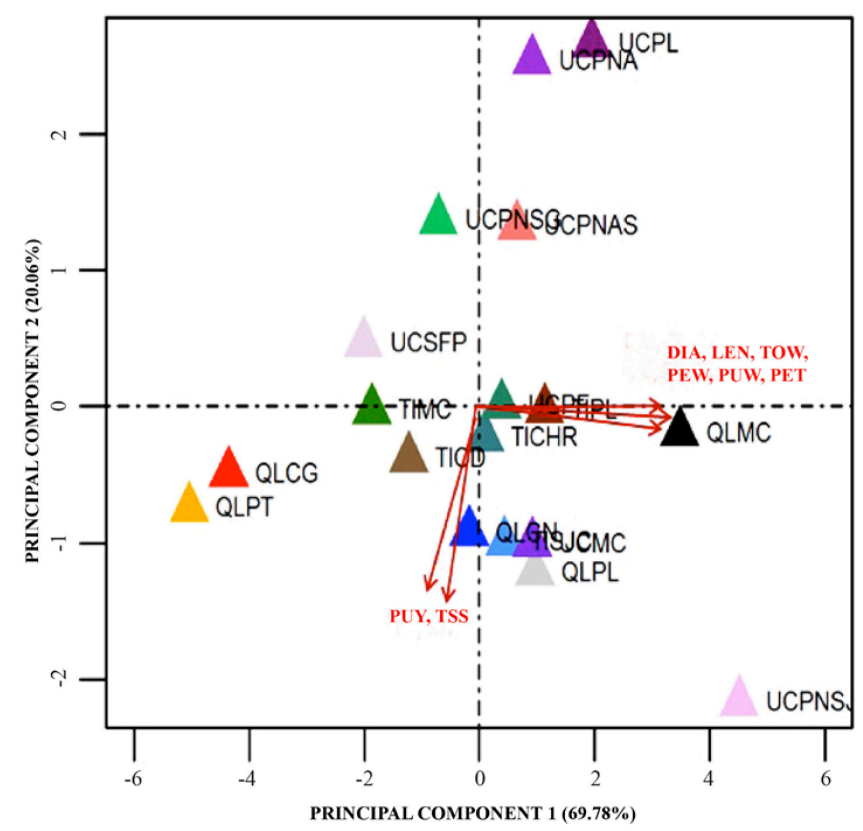

FIGURE 2-Principal Component Analysis (PCA) from the descriptors: diameter (DIA), length (LEN), total weight (TOW), pericarp weight (PEW), pulp weight (PUW), pulp yield (PUY), pericarp thickness (PET) and total soluble solids (TSS) analyzed in A. sellowiana fruits from 18 plant populations (See Table 1) located in Quilombola Communities (QLCG, QLCN, QLMC, QLPL, QLPT); Indigenous Lands (TICD, TICHR, TIMC, TIPL, TISJC) and Conservation Units (UCMC, UCPF, UCPL, UCPNA, UCPNAS, UCPNSG, UCPNSJ) in the south of Brazil. 
TABLE 3- Characteristics and differences (in percentage) between fruits of Uruguayan and Brazilian feijoa types obtained from 18 populations in the south of Brazil.

\begin{tabular}{lccc}
\hline \multicolumn{1}{c}{ Fruit Descriptors } & $\begin{array}{c}\text { Type Uruguay } \\
(\mathrm{n}=2)\end{array}$ & $\begin{array}{c}\text { Type Brazil } \\
(\mathrm{n}=16)\end{array}$ & Differences (\%) \\
\hline Diameter $(\mathrm{cm})$ & 2.5 & 3.7 & 32.4 \\
Length $(\mathrm{cm})$ & 3.2 & 4.3 & 25.06 \\
Total weight $(\mathrm{g})$ & 11.5 & 35.9 & 68.0 \\
Pericarp weight $(\mathrm{g})$ & 7.9 & 24.7 & 68.0 \\
Pulp weight $(\mathrm{g})$ & 3.7 & 11.2 & 67.0 \\
Pulp yield $(\%)$ & 31.6 & 31.7 & 0.3 \\
Pericarp thickness $(\mathrm{cm})$ & 0.3 & 0.5 & 40.0 \\
Total soluble solids $\left({ }^{\circ} \mathrm{Brix}\right)$ & 11.5 & 10.6 & -8.5 \\
\hline
\end{tabular}

TABLE 4- Main component scores based on eight fruit characteristics (continuous variables - average of the populations) of feijoa originated from 18 populations located in Quilombola Communities, Indigenous Lands and Conservation Units in the south of Brazil.

\begin{tabular}{lcc}
\hline \multicolumn{1}{c}{ Variables } & PC 1 (Axis 1) & PC 2 (Axis 2) \\
\hline Pericarp weight $(\mathrm{g})$ & 0.4189 & -0.0385 \\
Total weight $(\mathrm{g})$ & 0.4186 & -0.0939 \\
Diameter $(\mathrm{cm})$ & 0.4162 & -0.0360 \\
Length $(\mathrm{cm})$ & 0.4060 & -0.1133 \\
Pulp weight $(\mathrm{g})$ & 0.4053 & -0.2157 \\
Pericarp thickness $(\mathrm{cm})$ & 0.3716 & 0.3312 \\
Total soluble solids $\left({ }^{\circ}\right.$ Brix) & -0.0465 & -0.6469 \\
Pulp yield $(\%)$ & -0.0803 & -0.6330 \\
\hline
\end{tabular}

\section{CONCLUSION}

There is significant phenotypic variability in the eight characteristics evaluated in the analyzed fruits of the feijoa populations, being higher for total weight and pericarp thickness and lower for pulp yield and total soluble solids.

In the QLMC and UCPNSJ populations, feijoa with better agronomic performance for fruit quality were identified, with potential for using in participatory breeding programs for in situ on farm conservation and the development of new cultivars.

\section{ACKNOWLEDGEMENTS}

The authors thank to CAPES for the scholarship to LJB, the CNPq for financial support and scholarships to RON and LS and to FAPESC (Projects 9153/2010-7 and 5288/2011-4) for the financial support. 


\section{REFERENCES}

AMARANTE, C.D.; STEFFENS, C.A.; DUCROQUET, J.P.H.J.; SASSO, A. Qualidade de goiabeira-serrana em resposta à temperatura de armazenamento e ao tratamento com 1-metilciclopropeno. Pesquisa Agropecuária Brasileira, Brasília, DF, v.43, n.12, p.1683-1689, 2008.

BEYHAN, O.; EYDURAN, S.P. Determination of promising native Feijoa (Feijoa sellowiana Berg.) genotypes from Sakarya Region in Turkey. Scientific Research and Essays, Ebène, v.6, n.19, p.4104-4108, 2011.

CENTRO DE SOCIOECONOMIA E PLANEJAMENTO AGRÍCOLA - Epagri/ Cepa. Síntese Anual da Agricultura de Santa Catarina 2011-2012. Florianópolis: EPAGRI, 2013. 182p. Disponível em: $\leq$ http://cepa.epagri.sc.gov.br/ Publicacoes/Sintese 2010/sintese $\% 202010$ inteira. pdf $>$. Acesso em: 03 out. 2015.

DEGENHARDT, J.; DUCROQUET, J.P.; GUERRA, M.P.; NODARI, R.O. Avaliação fenotípica de características de frutos em duas famílias de meiosirmãos de goiabeira-serrana (Acca sellowiana Berg.) de um pomar comercial em São Joaquim, SC. Revista Brasileira de Fruticultura, Jaboticabal, v.25, n.3, p.475-479, 2003.

DONAZZOLO, J. Conservação pelo uso e domesticação da feijoa na serra gaúcha - RS. 2012. 312 f. Tese (Doutorado em Recursos Genéticos Vegetais) - Universidade Federal de Santa Catarina, Florianópolis, 2012.

DONAZZOLO, J.; ORNELLAS, T.S.; BIZZOCCHI, L.; VILPERTE, V.; NODARI, R.O. O armazenamento refrigerado prolonga a viabilidade de sementes de goiabeira-serrana. Revista Brasileira de Fruticultura, Jaboticabal, v.37, n.3, p.748-754, 2015.

DUCROQUET, J.P.H.J.; HICKEL, E.R.; NODARI, R.O. Goiabeira serrana (Feijoa sellowiana). Jaboticabal: Funep, 2000. 66p. (Série Frutas Nativas , 5)
DUCROQUET, J.P.H.J.; NUNES, E.C.; GUERRA, M.P.; NODARI, R.O. Novas cultivares brasileiras de goiabeira-serrana: SCS 414-Mattos e SCS 415-Nonante. Agropecuária Catarinense, Florianópolis, v.21, n.2, p.79-82, 2008.

ESEMANN-QUADROS, K.; MOTA, A.P.; KERBAUY, G.B.; GUERRA, M.P.; DUCROQUET, J.P.H.J.; PESCADOR, R. Estudo anatômico do crescimento do fruto em Acca sellowiana Berg. Revista Brasileira de Fruticultura, Jaboticabal, v.30, n.2, p.296-302, 2008.

MARTÍNEZ-VEGA，R.R.; FISCHER，G.; HERRERA, A.; CHAVES, B.; QUINTERO, O.C. Características físico-químicas de frutos de feijoa influenciadas por la posición en el canopi. Revista Colombiana de Ciencias Hortícolas, Bogotá, v.2, n.1, p.21-32, 2008.

MATTOS, J.R. A goiabeira serrana. Porto Alegre: Instituto de Pesquisas de Recursos Naturais Renováveis. 1986. 84p. (Publicação, 19).

MATTOS, J.R. Goiabeira serrana. Fruteiras nativas do Brasil. 2.ed. Porto Alegre: Gráfica CEUE, 1990. 120p.

MORETTO, S.P.; NODARI, E.S.; NODARI, R.O. A Introdução e os Usos da Feijoa ou Goiabeira Serrana (Acca sellowiana): A perspectiva da história ambiental. FRONTEIRAS: Journal of Social, Technological and Environmental Science, Anápolis, v.3, n.2, p.67-79. 2014.

NODARI, R.O.; DUCROQUET, J.P.H.J.; MELER, K.; GUERRA M.P. Genetic variability of Feijoa sellowiana germplasm. Acta Horticulturae, Leuven, v.452, p.41-46, 1997.

NODARI, R.O.; SANTOS, K.L.; DUCROQUET, J.P.; GUERRA, M.P. Goiabeira-serrana: domesticação. In: BARBIERI, R.L.; STUMPF, E.R.T. (Org.). Origem e evolução de plantas cultivadas. Brasília, DF: Embrapa Informação Tecnológica, 2008. p. 415-435.

PUPPO, M.; RIVAS, M.; FRANCO, J.; BARBIERI, R. L. Propuesta de descriptores para Acca sellowiana (Berg.) Burret. Revista Brasileira de Fruticultura, Jaboticabal, v.36, n.4, p.957-970, 2014 
R Development Core Team. R: A language and environment for statistical computing. Viena: R Foundation for Statistical Computing, 2014. Disponível em: $<$ http://www.R-project.org/>.

SANTOS, K.L.; GURIES, R.P.; NODARI, R.O.; PERONI, N. Traditional Knowledge and Management of Feijoa (Acca sellowiana) in southern Brazil. Economic Botany, New York, v.63, p.204214, 2009.

SHARPE, R.H.; SHERMAN, W.B.; MILLER, E.P. Feijoa history and improvement. Proceedings of the Florida State Horticultural Society, Winter Haven, v.106, p.134-139, 1993.
SILVEIRA, A.C.; OYARZÚN, D.; ZÁCCARI, F.; RIVAS, M. Determinación de algunos atributos de calidad en frutos de guayabo del país [Acca sellowiana (Berg) Burret] en diferentes estados de maduración. Agrociencia Uruguay, Montevideo, v.19, n.1, p.24-30, 2015.

SNEATH, P.H.; SOKAL, R.R. Numerical taxonomy: The principles and practice of numerical classification. San Francisco: W.H. Freeman, 1973. $573 p$.

THORP, G.; BIELESKI, R. Feijoas: origins, cultivation and uses. Auckland: David Bateman, 2002. 87 p. 